\title{
A Discussion on the Educational Administrative Staff System under the Reform of Educational Personnel System
}

\author{
Wenjia Pan \\ Tianjin University of Finance and Economics, Tianjin 300222, China. \\ 1139205158@163.com
}

Keywords: The Higher Education, Personnel Management, Administrative Staff System.

\begin{abstract}
The pilot college staff system has achieved great success since its release, with various colleges carrying out positive discoveries and accumulating precious experiences, yet facing several difficulties like blindness in the custom amendments due to uncertainties in the national level system formation, poor connectivity of administrative works distributed to different departments, or the wide range and complexity that this reform is influencing. Now, there are chances and challenges, while hope and dilemma coexist, this article is going to analyses the system in a macro point of view.
\end{abstract}

\section{Introduction}

There has been a long history of college staff system in the west countries, enabling them with sufficient experience. With development of higher education and further comprehensive reform in education domain, early $21^{\text {st }}$ century, the Ministry of Education introduced this Pilot College Staff Regulation according to relevant requirements in the Education Laws and Higher Education Laws. The regulation aims to implement a recruitment system that is sustainable and flexible enough in order to build up a competitive and effective college staff team. The Ministry of Education has chosen testing colleges and promoted the regulation gradually to achieve a better result. During 2000 - 2004, the Ministry of Education implemented the pilot system in 6 universities which are directly under the ministry, including Wuhan University and China Agricultural University. In the following decade, regional colleges of some provinces also initiated participation in the pilot schemes, as to date, the number of participating colleges is still increasing.

However, there is still not a feasible system forming from the 10 years of testing, this incomplete implementation has indicated to some extent that the reform of personnel system is indeed affecting the whole situation as well as various domains. Nonetheless, this reform is in increasing demand as the comprehensive reform in education domain is going deeper, following college management system reform; call of improving management and enhancing college administration team is increasing as well. From 2000 onwards, colleges have carried out positive discoveries and accumulated precious experiences, but also facing significant dilemma at the same time, hereby stating several observations as follows.

\section{Dilemma of College Personnel System}

\subsection{Blindness in the custom amendments due to uncertainties in the national level system formation}

Although, both the pilot regulation introduced by the Ministry of Education and pilot schemes that regional colleges came up with to promote staff system have emphasized their aim to enhance administration team building and improve management standards through system innovation, in order to push higher education towards better development, in actual practice, the nature of implementing staff system has become how to solve staff promotion and wage involved issues. Management teams of colleges tend to attribute issues like position - technique conflict and wage problems to lag in system reform, simply deeming college staff system as the omnipotent solution for all position, wage and staff positivity problems. As the nation has not confirmed a finalised and united system, blindness and randomness become inevitable in college custom amendments. The production of staff system 
faced a great limitation due to over benefit-oriented direction which too much focus was put on adding positions and raise wage levels from the implementation of staff system, deviated from the origin of building a professional administration team, where innovations on position setting, employing, and examining are ignored.

\subsection{Poor connectivity of administrative works distributed to different departments}

In the current administration structure, administrative works are highly separated and distributed to different departments. Policies introduced can be poorly connected or even conflicted. For example, Organization Department can hold the authority to appoint executive level positions, where Administrative Establishment Department can hold the authority of position setting, and Ministry of Human Resources and Social Security verifies the structure and ratio of different type of positions based on the inner organizations and executive numbers agreed by Administrative Establishment Department. This decentralization of power seems to be able to bring more justice and fairness, but in fact, they are only standing in their own opinions and concerns regarding the system reform, resulting in the lag in reform implementation and incomplete formation of new system. Without duly support from these authorities, colleges seem not able to implement the staff system at all.

\subsection{Wide range and complexity being influenced}

Although the implementation of staff system has been mentioned many times in supporting document from the law and different relevant department, the difficulty level of implementation was raised as the content and scope were specified neither in legal documents nor in department regulations. At the same time, lack of corresponding supporting system, like organization category, distribution system, and wage and retirement standards, is leading to conflicts with current position, wage, employment and retirement policies under current administration structure. The connection between policies has become the very barrier of implementing reformed system[1]. Performance wage system works better for professionals, and the wage system for administrative personnel was purposely put lower than professionals, which makes administrative personnel lose their enthusiasm. Additionally, current position setting also tends to benefit professionals more as administrative positions shrink for more professional positions and senior professional titles. A lot of educational management professionals are also taking administrative duties in colleges. Some colleges allow professional and administrative personnel have better privilege at the same time, but the limitation of number of positions and titles remains difficult for promotion through the system like a pyramid. The pilot regulation and regional pilot schemes were not able to solve the difficulties and issues above well, and professional management team building has not reached a good result as well.

\section{Prospect of Administrative Staff System}

Despite these dilemmas mentioned above, being a newly introduced form, the staff system has a strong vitality and development prospects.

\subsection{Make the staff system legal}

In the Higher Education Laws, it has provided the legal reference by proposing higher education staff system building, which is indeed the very beginning of professionalization and reorientation of college administrative personnel. The construction and implementation of the educational staff system in colleges is a process of professionalization of administrative staff. The system follows the regulations in the Higher Education Laws, and tallies with the reform of institution personnel system, but it is yet urgent work to discover how to build a feasible and sustainable one. The demand of the system, which has been of great concern since its launch, is increasing with the deepening of comprehensive reform of institution personnel system[2].

The Education Laws and the Higher Education Laws have shown the legal validity of the system. The years of practicing the pilot regulations also meant to discover a more feasible way for actual implementation.

\subsection{The endogenous power of the personnel system in colleges}

The development of higher education is closely related to the stability of the administrative team and the improvement of management efficiency. Hence, the top-level production of the system is crucial, and it is the inevitable path of personnel system reform in Higher Education Institutions to 
implement the educational staff system. The implementation of the reform of personnel system in colleges can fundamentally solve the three existing problems in the administrative team of colleges of the original system: 1 . to cancel the "official" administrative ranks of administrative personnel and to avoid "government-oriented" tendency, which weakens the concept of position and level, and enhances the consciousness of serving; 2 . to solve the problems of position - technique conflicting and disorganizing, which overcomes the embarrassment of staff vacillate between their positions and professional skills, and clarifies position setting and post ranking sequence, in order to make up the relationship of college administrative personnel, teaching staff and other assistant professionals; 3 . to clarify the relationship of wage, which builds suitable wage series according to staff ranking and college situation, allowing systematic and orderly promotions and respective wage and allowance, which can better show rules of position - wage - work balance, in order to stimulate the initiative and enthusiasm of the main body of the college management and to enhance the effectiveness of management and the quality of service[3].

\subsection{Optimization of external conditions for the college staff system}

The implementation of college personnel system is the inevitable trend of deepening the reform of personnel administrative system in colleges. Large amount of practical explorations after ten years of testing have provided a priori conditions for the formulation of relevant rules and policies, and hence a stronger foundation of further implementation. After continuous reform in recent years, social awareness and demand are increasing, and all aspects of the conditions are gradually improving to accomplish. The Regulations on Personnel Management of Institutions promulgated in 2014 and following relevant regulations presented by regional institutions on standardising personnel management of public institutions have pointed a clear direction for deepening the reform of personnel system. The "Opinions of the National Education System Reform Leading Group Office on Further Implementation and Expansion of the Autonomy of Colleges to Improve the Internal Governance Structure[4]" explicitly claimed that, the construction of professional administrative team in colleges is greatly supported; the college staff system shall be further implemented and administrative personnel promotion channels shall be broadened. This has created a good atmosphere for deeper reform of college staff system.

\section{Some Suggestions on the Implementation of the Staff System}

Firstly, management concept should be updated. Both producers and executors of the system must in clear awareness of the purpose of the implementation, and set the framework and promote its implementation according to rules of management science. Secondly, colleges shall not be inclined to the forefront of educational research positions all the time when distributing resources, key administrative positions should also be given certain priority to enhance the status of school administrators. Allocation of resources for administrative positions shall not be set to be fewer from the early stages of system production. Last but not least, to get rid of system barrier, deeper issues like cadre identity management, wage and salary and staff appointment have to be tackled, in order to release administrative staff from administrative ranks and turning them from the passive targets of the reform to active supporters, and hence clearing ideological obstacles. For overall implementation of reform, although departments have different opinions towards the system reform, they should be jumping out from their own benefit and enhancing cooperation, aiming to promote the implementation of comprehensive reform in education domain as a whole, in order to make a better atmosphere for the reform.

\section{References}

[1]. Jian Sun, The Attempting Discussion of the College Staff System Reform, Heilongjiang Researchs on Higher Education, 2007(5), p.115-117.

[2]. Jun Wang, the Dilemma and Hope of the College Staff System, A study of Chinese teachers in Colleges and Universities, 2014(5), p.19-24. 
[3]. Yi Cheng, Analysis of Staff System Reform in University Administrative Staff, Journal of Liaoning Educational Administration Institute, 2016(3), p.18-20.

[4]. Information on: www. moe. edu.cn /publicfiles /business/ htmlfiles /moe/s6529 /201412/1 82222. html. 